\title{
Study of Bacterial contamination of Vacuum packaged Fish obtained from Ahvaz market
}

\author{
Samira Mohammadi ${ }^{1}$, Masrour Zakeri Nasab ${ }^{2}$, Zahra Khoshnood ${ }^{3 *}$ \\ 1- Msc student of Microbiology, Department of Biology, College of Science, Dezful Branch, Islamic Azad University, \\ Dezful, Iran. \\ 2- Department of Marine Biology, Faculty of Natural Resources and Environment, Science and Research Branch, Islamic \\ Azad University, Tehran, Iran \\ 3- Department of Biology, College of Science, Dezful Branch, Islamic Azad University, Dezful, Iran.
}

(C) 2017 Journal of the Persian Gulf. All rights reserved.

\begin{abstract}
Keeping health and nutritional value of the packed foods has a great value in food industries. Among the diverse methods of food processing and packaging, vacuum packaging is one of the best methods for a variety of food products, such as fish. In order to evaluate the effectiveness of such method in preventing of bacterial growth during preservation of fish fillets, four vacuum packed fish of Scomberomorus commerson, Saurida tumbil, Otolithes ruber, and Oreochromis niloticus were investigated. Using microbial cultivation followed by speciesspecific culture media and staining showed negative growth of Enterococcus sp., but positive growth of Escherichia coli and Listeria sp. Results showed that the highest microbial contamination of four studied fillets was as follow: Otolithes ruber> Oreochromis niloticus $>$ Scomberomorus commerson > Saurida tumbil. Results also showed that as a variety of microbial species contamination, the most contaminated fillet belong to Oreochromis niloticus. Results of the present study showed that vacuum packaging was un-successful against the growth of the Escherichia coli and Listeria sp., but fully successful against the Enterococcus $s p$. In conclusion, it seems that vacuum packaging needs to be paired with other hygienic methods for keeping bacterial growth out of the fish fillets.
\end{abstract}

Keywords: Bacterial contamination, Vacuum packaging, Fish, E.coli

\section{Introduction}

Keeping the health, preservation for long times, transport, and maintenance of the nutritional value of all food products were all possible due to suitable packaging which would be conservative for foods

*Email: ZKhoshnood@gmail.com against malicious and corrupting factors, such as microbial, physical and chemical factors. Vacuum packaging is one the most common and effective methods of food packaging which increases the product shelf life and to keep the quality of the packaged food (Mendes and Goncalvez, 2008). Aquaculture has the fastest growth among the various agricultural industries so that the global catch 
and aquaculture was predicted as 154 million tons (FAO, 2013). As well as raising awareness about the economic importance of fish farming, studies and research on bacterial diseases have also been increasingly growing. The microbial status of the caught fish is closely related to the environmental conditions and microbial quality of the water. Other factors include water temperature, salinity, a distance between fishing grounds and evacuation stations, infected areas of freezing, and treatments and postharvest manipulations (Baker et al., 2010). Fish aerobic corruption is mainly attributed to gramnegative bacteria, but with the advancement in fishprocessing technologies, opportunities for the growth of gram-positive bacteria and their dominance are more likely to result in corruption (Gram, 2009). Ecologically and corruptible, gram-positive bacteria appear to be lower in number in comparison with other bacterial groups, but have this characteristic of mutual activity with other bacteria in corruption (Gram, 2009).

It has been revealed that maintenance and growth of the microorganisms in food are not only dependent on chemical properties of the food, but also to conservation conditions (Perez-Alonso et al., 2004). Enzymatic and microbial activities are two major factors for corruption of the fish fillets. A wide range of pathogenic bacteria in food products have the ability of adherence to surfaces and remain active even after hygienic processes. It has also been showed that microbial pollution of the environment could affect the food products directly or indirectly (Lalitha et al., 2005). Bacteria are the most abundant category of microorganisms that cause infections in humans through the consumption of infected fish. The most well-known food pathogenic bacteria are Listeria monocytogenes, Aeromonas spp., Pseudomonas spp., Enterococcus faecalis, and Streptococcus spp. (Bagge-Ravn et al., 2003). In recent years, consumption of infected seafood to Enterococcus, Streptococcus and Listeria have caused some major illnesses in humans (Arashisar et al., 2004). Due to the importance of maintaining the health quality of packaged foods, we studied the microbial contamination of packed fish fillets obtained from Ahvaz market, Iran.

\section{Materials and Methods}

\subsection{Collecting of packaged fish fillets}

Vacuum packaged fish fillets of four fish species (Otolithes ruber, Saurida tumbil, Oreochromis niloticus and, Scomberomorus commerson) were collected from Ahvaz market (Iran) during summer 2017. All specimens were licensed from the health center and their expiration date was not over. The total number of 100 fillets was collected, as 25 specimens for each fish species. All samples were of the same size and weight and kept under the same temperature conditions.

\subsection{Microbial examination}

In order to determine the general presence of bacteria in examined fillets, and total bacterial count, swab samples taken from fillets were cultured on two culture media of Nutrient Agar (NA) and Plate Count Agar (PCA) (Tavakoli et al., 2012). After 24h of incubation at $37^{\circ} \mathrm{C}$, plates were examined for bacterial growth followed by gram staining (Tavakoli et al., 2012). The specific eosin methylene blue (EMB) culture media was used for isolation of the E. coli (Goldberg, 2001). The specific Bile Esculin Agar (EBA) culture media of $6.5 \%$ salt was used for isolating the Enterococcus sp., followed by blood agar (BA) culture media and catalase test (Goldberg, 2001) (Table 1).

For the isolation of the Listeria sp., Blood agar culture media was used followed by Listeriaspecific selective agar culture media, which the latter followed by blood agar culture media kept in $4{ }^{\circ} \mathrm{C}$ for 
$24 \mathrm{~h}$ and finally examined by catalase test (Erdogan et al., 2002) (Table 2).

All cultures and growth tests included the negative control (same culture media without any samples for each step) for verification of the non-contamination to ensure the correct operation of the laboratory tests (Erdogan et al., 2002).

Statistical analysis was performed by one-way ANOVA test using SPSS 16.0.

Table 1: Biochemical tests used for identification of the Entrococcus sp.

\begin{tabular}{lccc}
\hline Test & Growth in Esculin Bile Agar of 6.5\% salt & Growth in blood agar & Catalase \\
\hline Response & + & - & + \\
\hline
\end{tabular}

Table 2: Biochemical tests used for identification of the Listeria sp.

\begin{tabular}{lcccccc}
\hline Test & Catalase & oxidase & Motility at $25^{\circ} \mathrm{C}$ & Growth in $25^{\circ} \mathrm{C}$ & BA at $4^{\circ} \mathrm{C}$ & Hemolysis \\
\hline Response & + & + & + & + & + & + \\
\hline
\end{tabular}

\section{Results}

Results of the bacterial growth from different fish fillets showed that multiple culture media had positive growth in all fish fillet samples, except for the EMB for O. ruber and S. tumbil (Table 3). Results of this positive growth confirms the presence of bacteria in studied fillets.

Results of the bacterial count for each fish species are shown in Table 4. Fillets of Otolithes ruber showed the highest number of bacteria on PCA, illets of Saurida tumbil on EBA, and fillets of Oreochromis niloticus on PCA and EBA, all with significant differences $(\mathrm{p}<0.05)$. There was no significant difference for fillets of Scomberomorus commersonon all culture media $(\mathrm{p}>0.05)$.

Results of the bacterial identification in fillets of four fish species is shown in Table 5. Results showed that Listeria monocytogenes and Escherichia coli were present on some fillets and the Entrococcus $s p$. on none of the samples.

Table 3: Bacterial growth in studied culture media from 4 fish species.

\begin{tabular}{|c|c|c|c|c|c|}
\hline $\begin{array}{c}\text { Culture media } \\
\text { Fish species }\end{array}$ & PCA & NA & EMB & $\mathbf{B A}$ & EBA \\
\hline Otolithes ruber & + & + & - & + & + \\
\hline Scomberomorus commerson & + & + & + & + & + \\
\hline Saurida tumbil & + & + & - & + & + \\
\hline Oreochromis niloticus & + & + & + & + & + \\
\hline
\end{tabular}

PCA: Plate count agar; NA: Nutrient agar; EMB: Eosin methylene blue; BA: blood agar; EBA: Esculin Bile Agar. 
Khoshnood et al. / Study of Bacterial contamination of Vacuum packaged fish obtained...

Table 4: Bacterial count of different fish fillets in studied culture media (Log cfu/g)

\begin{tabular}{|c|c|c|c|c|c|}
\hline $\begin{array}{c}\text { Culture media } \\
\text { Fish species }\end{array}$ & PCA & NA & EMB & $\mathbf{B A}$ & EBA \\
\hline Otolithes ruber & $1.2 \times 10^{5} \pm 0.0^{\mathrm{b}}$ & $1.2 \times 10^{4} \pm 0.1^{\mathrm{a}}$ & - & $1.2 \times 10^{4} \pm 0.0^{\mathrm{a}}$ & $1.2 \times 10^{4} \pm 0.0^{\mathrm{a}}$ \\
\hline $\begin{array}{l}\text { Scomberomorus } \\
\text { commerson }\end{array}$ & $1.1 \times 10^{4} \pm 0.05^{\mathrm{a}}$ & $1.2 \times 10^{4} \pm 0.1^{\mathrm{a}}$ & $1 \times 10^{4} \pm 0.1^{\mathrm{a}}$ & $1.2 \times 10^{4} \pm 0.0^{\mathrm{a}}$ & $1.2 \times 10^{4} \pm 0.0^{\mathrm{a}}$ \\
\hline Saurida tumbil & $0.5 \times 10^{4} \pm 0.1^{\mathrm{c}}$ & $1.2 \times 10^{1} \pm 0.0^{\mathrm{a}}$ & - & $1.2 \times 10^{2} \pm 0.1^{\mathrm{b}}$ & $1.2 \times 10^{4} \pm 0.1^{\mathrm{d}}$ \\
\hline Oreochromis niloticus & $1.2 \times 10^{4} \pm 0.0^{\mathrm{c}}$ & $1.2 \times 10^{4} \pm 0.0^{\mathrm{a}}$ & $1 \times 10^{3} \pm 0.1^{\mathrm{b}}$ & $1.2 \times 10^{1} \pm 0.0^{\mathrm{a}}$ & $1.2 \times 10^{4} \pm 0.0^{\mathrm{c}}$ \\
\hline
\end{tabular}

PCA: Plate count agar; NA: Nutrient agar; EMB: Eosin methylene blue; BA: blood agar; EBA: Esculin Bile Agar.

Table 5: Bacterial Identification in fish fillets.

\begin{tabular}{lccc}
\hline \multicolumn{1}{c}{$\begin{array}{c}\text { Bacteria } \\
\text { Fish }\end{array}$} & $\begin{array}{c}\text { Listeria } \\
\text { monocytogenes }\end{array}$ & Escherichia coli & Entrococcus sp. \\
\hline Otolithes ruber & + & - & - \\
Scomberomorus commerson & - & + & - \\
Saurida tumbil & + & - & - \\
Oreochromis niloticus & + & + & - \\
\hline
\end{tabular}

The total percent of each bacterium in all experimental specimens is shown in figure 1. As the results showed the most abundant species was Listeria sp.

Results showed that the presence of Listeria sp. in studied fillets was as follows: Otolithes ruber> Saurida tumbil> Oreochromis niloticus. No growth was observed for Listeria sp. in Scomberomorus commerson fillets. No significant differences were observed for the presence of Listeria sp. in three contaminated fillets (Figure 2).

Results showed that the presence of $E$. coli in studied fillets was as follows: Scomberomorus commerson > Oreochromis niloticus. No growth was observed for $E$. coli in fillets of Otolithes ruber and
Saurida tumbil. No significant differences were observed for the presence of $E$. coli in two contaminated fillets (Figure 3).

Results also showed that as the total microbial load of the observed fillets, Oreochromis niloticus was the most contaminated fillet. The mean total microbial load of Oreochromis niloticus was significantly higher than the other three observed fillets $(\mathrm{p}<0.05)$ (Figure 4$)$.

Results of the comparison between the abundance of observed bacteria in four experimental fish fillets showed that the most abundant species was Listeria sp. $\quad(\mathrm{p}<0.05), \quad$ as previously described, no Enterobacter species was observed in experimental fillets (Figure 5). 


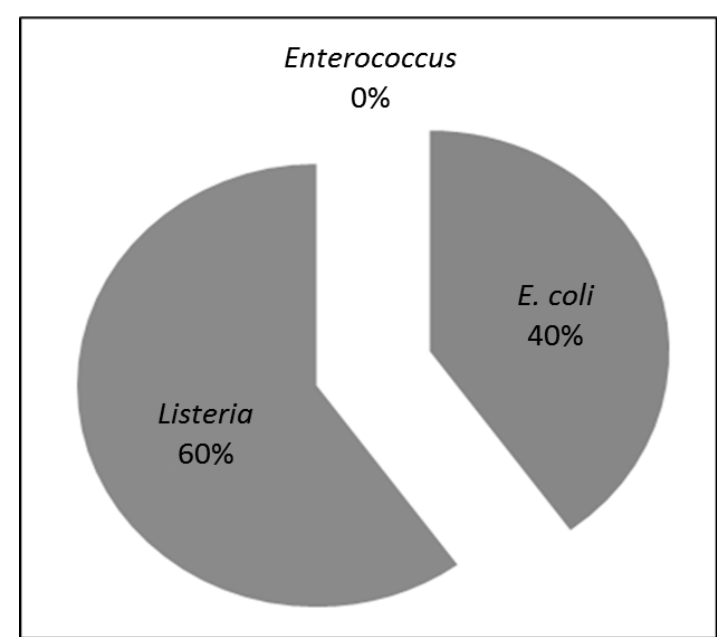

Fig 1: Presence of each bacterium in experimental fish fillets.

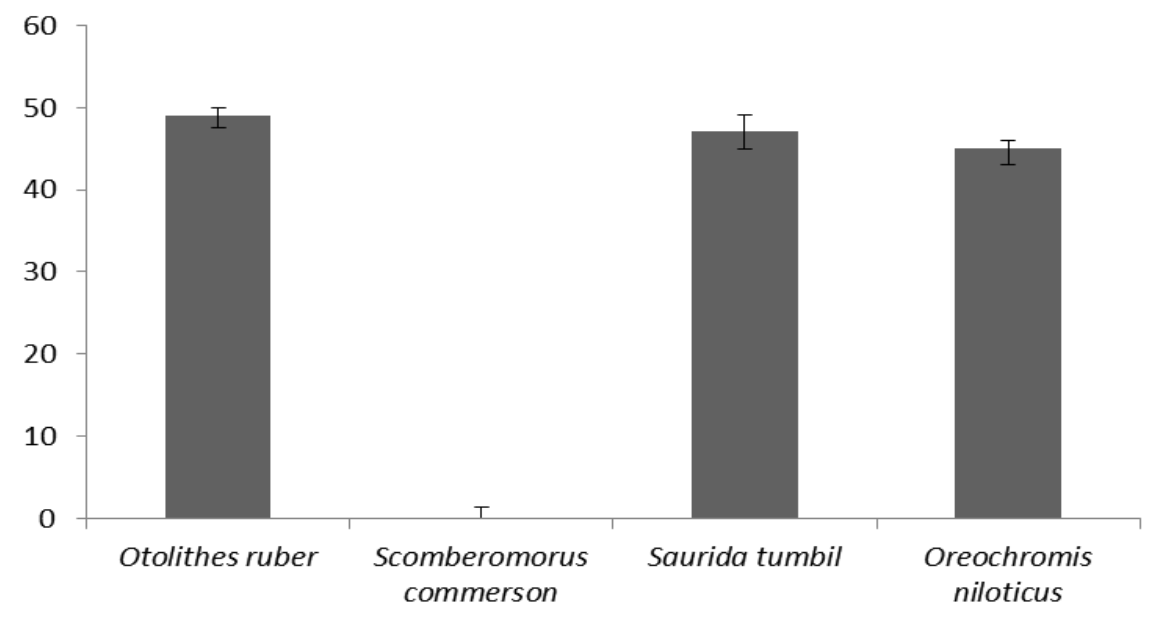

Fig 2: Contamination of observed fish fillets to Listeria sp.

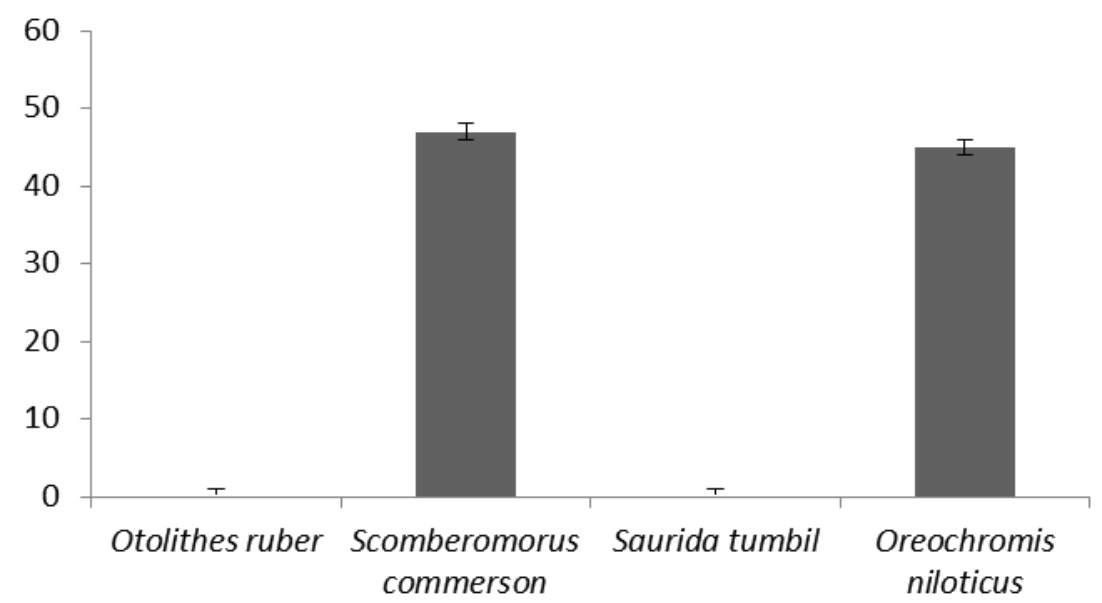

Fig 3: Contamination of observed fish fillets to E.coli. 


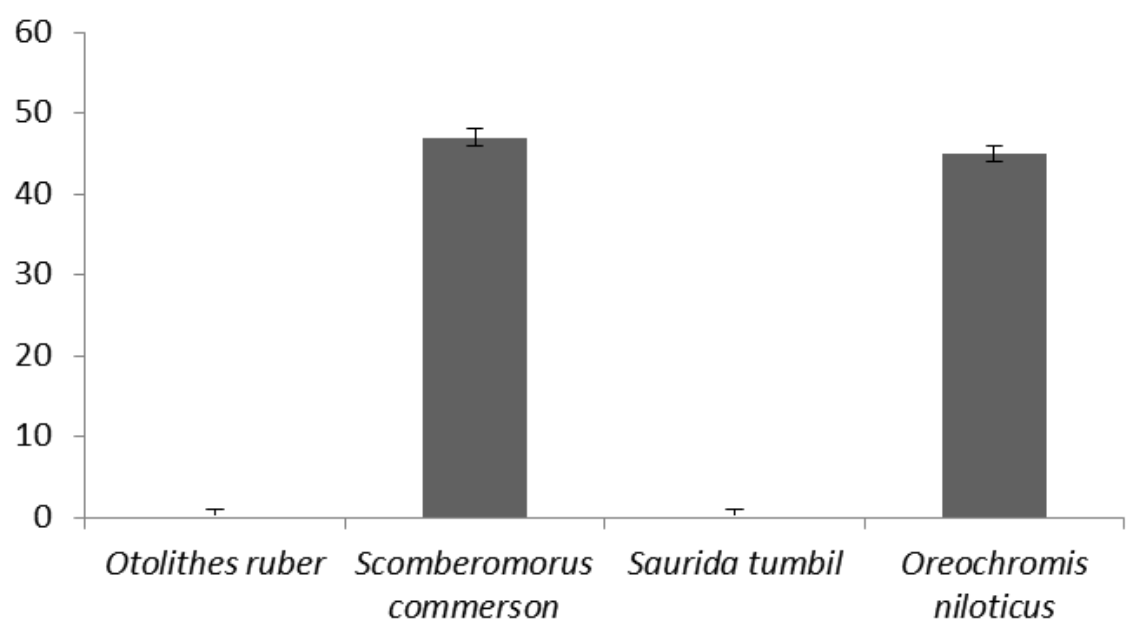

Fig. 4: The total microbial load of observed fish fillets

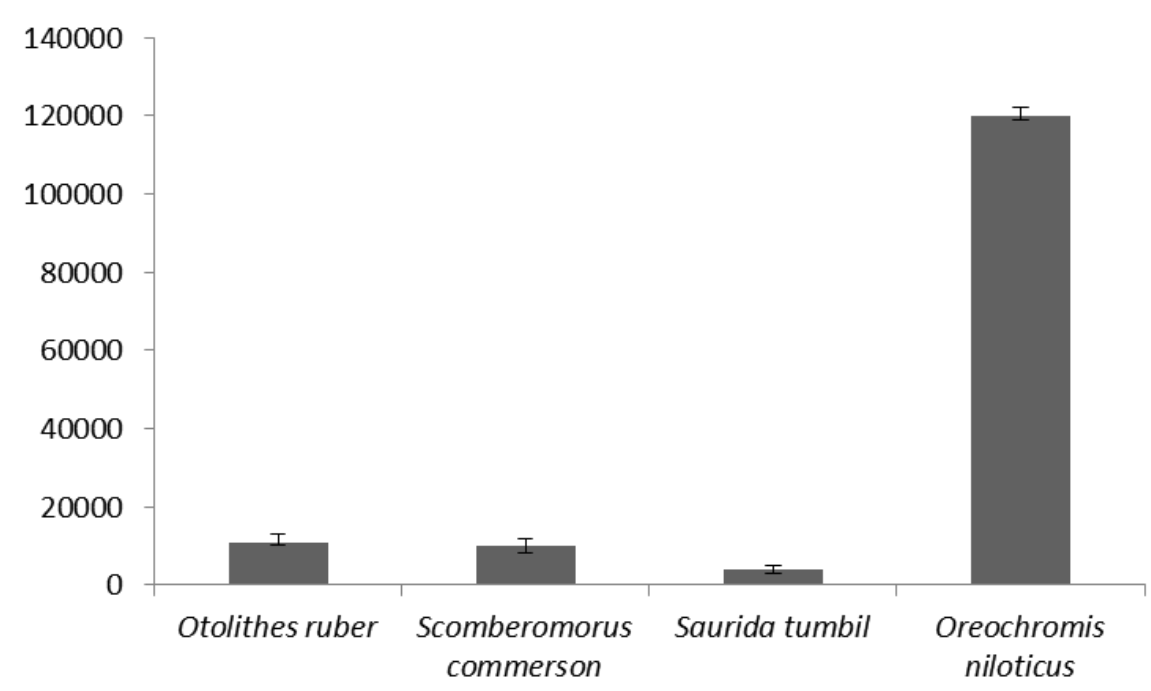

Fig 5: Comparison between the total abundance of observed bacteria in four experimental fish fillets

\section{Discussion}

Preventing the growth of pathogenic bacteria and increasing the shelf-life of fish as a spoilage food source by using safe methods is under the attention to the safety and quality of fishery products. It has been revealed that Listeria monocytogenes which causes the Listeriosis is one the most important pathogenic bacteria in meat products and one of the main concerns of health issues (Lyhs et al., 2001). New methods of packaging are one of the main ways for preventing the contamination of food products to Listeria, E. coli, and Enterococcuses.

It has been recognized that vacuum packaging is one of the most suitable packaging methods for postponing the corruption of marine products (Yassoralipour et al., 2016). Results of the present study showed no contamination of fillets to Enterococcus, which shows that vacuum packaging was fully successful in order to inhibit growth of such bacteria. On the other hand, the other two 
observed fish fillets were contaminated as $8.33 \%$ and $12.5 \%$ to E. coli and Listeria sp. respectively.

In a previous study, the outbreak of Listeria sp. in local markets of silver carp and common carp in Iran were revealed as $10 \%$ and $17.5 \%$, respectively (Akhondzadeh et al., 2003) which closely compares to the results of the present study. It has been reported that $8 \%$ of carps and $2 \%$ of clupeids in a case study in Iran (Tavakoli, 2012) were contaminated to E.coli. The differences between the total bacterial load of previous studies and the present study can be explained by the differences in fish species, maintenance conditions and processing differences.

The presence of bacteria is one of the major causes of corruption and deterioration of the quality of fish fillets during storage time. Therefore, generally, total bacterial load estimates are used as an accepted indicator in standards (Arashisar et al. 2004). The ICMSF has determined the limit of Log $10^{7} \mathrm{cfu} / \mathrm{g}$ for the bacterial load in a raw fish (ICMSF, 1986).

According to the presented results, the microbial load of the observed fish fillets of the present study were all in permitted range. In general, the rate of microbial decay of fish and its products depends on the microbial flora, ambient temperature and fish species (Guillern-Regost et al., 2006). Several factors, such as manipulation during filleting, contamination of the equipment and the health of persons involved in the work, determine the initial rate of bacterial load of the fillet, which justifies the different microbial burden of the fillets. According to the results, vacuum packaging was successful in order to preventing the presence and growth of the Enterococcus sp., but not successful in the case of contamination to E. coli and Listeria sp.

\section{Conclusions}

There are numerous studies about heavy metal, and other elements in the Persian Gulf. Although two ROPME cruises held in this region, but there are some unknown aspects about elements like REEs. This research carried out in order to the investigation some of REEs elements, and its relation to sediment texture, carbonate, and Tom. The result reveals that all elements have less value than average shale and upper crust. La has minimum concentration among elements $(0.01 \mu$ gg- 1) and Ce has the maximum level (19 $\mu$ gg1). REEs ratio $\mathrm{La} / \mathrm{Sc}$ (1.6) and $\mathrm{Ce} / \mathrm{La}$ ratio (2.1) were below the (UCC) and average shale (AS) ratios. Among selected elements, Ce show enrichment and other elements have $\mathrm{EF}<1$. The correlation between carbonate and REEs were negatively strong which is due to the REE depletion in the marine carbonates. Some REES like La and Ce have an anthropogenic source. Except La, other elements have CVs (>30\%), suggesting that their distributions might be influenced by anthological source. Spatial distribution of selected REEs in GIS approved the previous finding as well. Further investigation in REEs concentration in river flow as well as dry deposition can provide more accurate clue about actual source of REEs in the Persian Gulf.

\section{References}

Akhondzadeh, A., Zahraie Salehi, T., Misaghi, A., (2003). The survey of Listeria monocytogenes in fresh and smoked fish and ice used in fish markets for retaining the freshness of the fish in Tehran and Gilan. Journal of Veterinary Research, 57(4), 9-12.

Arashisar, S., Hisar, O., Kaya, M., Yanik, T., (2004). Effects of modified atmosphere and vacuum packaging on microbiological and chemical properties of rainbow trout (Oncorynchus mykiss) fillets. International Journal of Food Microbiology, 97(2), 209-214.

https://doi.org/10.1016/j.ijfoodmicro.2004.05.024 
Bagge-Ravn, D., Ng, Y., Hjelm, M., Christiansen, J.N., Johansen, C., Gram, L., (2003). The microbial ecology of processing equipment in different fish industries-analysis of the microflora during processing and following cleaning and disinfection. International Journal of Food Microbiology, 87(3), 239-250.

https://doi.org/10.1016/S0168-1605(03)00067-9

Bakar, J., Yassoralipour, A., Bakar, F.A., Rahman, R.A., (2010). Biogenic amine changes in barramundi (Lates calcarifer) slices stored at $0^{\circ} \mathrm{C}$ and $4^{\circ} \mathrm{C}$. Food Chemistry, 119(2), 467-470. https://doi.org/10.1016/j.foodchem.2009.06.041

Erdogan, H.M., Cripps, P.J., Morgan, K.L., (2002). Optimization of a Culture Technique for the Isolation of Listeria monocytogenes from Faecal Samples. Journal of Veterinary Medicine Bulletin of Infectious Disease and Veterinary Public Health, 49(10), 502-6.

https://doi.org/10.1046/j.1439-0450.2002.00601.x

FAO, Media center., (2013). Culprit behind massive shrimp die-offs in Asia unmasked. Bacterium responsible for Early Mortality Syndrome of Shrimp-Crucial first step in finding effective ways to combat the disease. (http://www.fao.org/news/story/en/item/175416/ic ode/).

Goldberg, M., (2001). Actin-Based Motility of Intracell- Uiar Microbial Pathogens. Microbiol and Molecular Biology Reviews, 65(4), 595-626. https://doi.org/10.1128/MMBR.65.4.595-626.2001

Gram, L., (2009). Microbiological Spoilage of Fish and Seafood Products. Compendium of the Microbiological Spoilage of Foods and Beverages, Springer-Verlag New York, 1st Ed. 87-119. (DOI: 10.1007/978-1-4419-0826-1). https://doi.org/10.1007/978-1-4419-0826-1_4

Guillen, M.D., Ruiz, A., (2004). Study of the oxidative stability of salted and unsalted salmon fillets by $\mathrm{H}$ nuclear magnetic resonance. Journal Food Chemistry, 86: 297-304.

https://doi.org/10.1016/j.foodchem.2003.09.028

ICMSF., (1986). Microorganisms in Foods 2. Sampling for microbiological analysis: Principles and specific applications. 1986. 2nd Ed. Oxford, England : Blackwell Scientific Publications.

Lalitha, K.V., Sonaji, E. R., Manju, S., Jose, L., Gopal, T. K. S., Ravisankar, C.N., (2005). Microbiological and biochemical changes in pearl spot (Etroplus suratensis Bloch) stored under modified atmospheres. Journal of Applied Microbiology, 99(5), 1222-8. https://doi.org/10.1111/j.1365-2672.2005.02694.x

Lyhs, U., Lahtinen, J., Fredriksson-Ahomaa, M., Hyyti a-Trees, E., Elfing, K., Korkeala, H., (2001). Microbiological quality and shelf-life of vacuum packaged 'gravad' rainbow trout stored at 3 and $8^{\circ} \mathrm{C}$. International Journal of Food Microbiology, 70, 221-230.

https://doi.org/10.1016/S0168-1605(01)00548-7

Mendes, R., Goncalvez, A., (2008). Effect of soluble $\mathrm{CO} 2$ stabilization and vacuum packaging in the shelf life of farmed sea bream and sea bass fillets. Journal of Food Science and Technology, 43, 1678-1687.

https://doi.org/10.1111/j.1365-2621.2008.01737.x

Perez-Alonso, F., Aubourg, S.P., Rodriguez, O., Barros-Velazquez, J., (2004). Shelf life extension of Atlantic pomfret (Brama brama) fillets by packaging under a vacuum-skin system. Journal of Food Research Technological, 218, 313-317. https://doi.org/10.1007/s00217-003-0831-z

Tavakoli, H.R., Soltani, M., Bahonar, A., (2012). Isolation of some human pathogens from fresh and smoked shad (Alosa kessleri) and silver carp (Hypophthalmichthys molitrix). Iranian Journal of Fisheries Sciences, 11 (2), 424- 429. 
Yassoralipour, A., Bakar, J., Rahman, R. A., Fatimah, A., Bakar, B., Özogul, F., (2016). Effects of modified atmosphere packaging on microbiological load and physico-chemical properties of barramundi (Lates calcarifer Bloch) fillets at $8^{\circ} \mathrm{C}$. Iranian Journal of Fisheries Sciences, 15(1), 457- 469. 
